\title{
ERRATUM
}

Sung-Jin Cho · Dae-Hee Lee - Hyuk-Jae Kwon •

Chi Hyun Ahn - Soon Cheol Park - Kil-Sang Shin

\section{Hox genes in the echiuroid Urechis unicinctus}

Published online: 25 April 2006

(C) Springer-Verlag 2006

\section{Dev Genes Evol (2006): D0I 10.1007/s00427-006-0058-7}

The names of contributing authors have been shown in wrong sequence in the original publication. The correct sequence is given above.

The original article can be found at http://dx.doi.org/10.1007/ s00427-006-0058-7.

Sung-Jin Cho and Dae-Hee Lee contributed equally to this work.

S.-J. Cho · C. H. Ahn · S. C. Park

Department of Life Science, Chung-Ang University,

221 Hukseok-Dong, Dongjak-Ku,

Seoul, 156-756, Republic of Korea

e-mail: scpark@cau.ac.kr

Tel.: +82-2-8205212

Fax: $+82-2-8205212$

D.-H. Lee · H.-J. Kwon · K.-S. Shin $(\bowtie)$

Department of Life Science, College of Natural Science,

Soonchunhyang University,

Asan, Chungnam 336-745, Republic of Korea

e-mail: Shinks@sch.ac.kr

Tel.: +82-41-5301252

Fax: $+82-41-5301256$

Present address:

S.-J. Cho

Department of Molecular and Cell Biology, 385 LSA,

University of California,

Berkeley, CA 94720-3200, USA 